\title{
Peningkatan pH Saliva dengan Mengunyah Keju Cheddar
}

\author{
${ }^{K}$ R. Ardian Priyambodo ${ }^{1}$, Ira Liasari ${ }^{2}$ \\ 1,2Jurusan Kesehatan Gigi, Poltekkes Kemenkes Makassar \\ Email Penulis Korespondensi $\left({ }^{\mathrm{K}}\right)$ : ardian@poltekkes-mks.ac.id
}

\begin{abstract}
ABSTRAK
Derajat keasaman $\mathrm{pH}$ saliva merupakan bagian yang penting dalam meningkatkan integritas gigi karena dapat meningkatkan terjadinya remineralisasi gigi, dimana penurunan $\mathrm{pH}$ saliva dapat menyebabkan demineralisasi gigi. Salah satu makanan yang dapat mempengaruhi pH saliva adalah keju.Tujuan penelitian ini adalah untuk mengetahui pengaruh makan keju cheddar terhadap peningkatan $\mathrm{pH}$ saliva. Penelitian ini adalah penelitian quasi experiment, dengan menggunakan pendekatan cross sectional dengan menggunakan rancangan penelitian pretest-posttest. Adapun jumlah sampel dalam penelitian ini adalah 67 orang. Analisis menggunakan uji paired T-test menujukkan hasil yang signifikan $(p=0,012)$, sehingga dapat disimpulkan bahwa ada peningkatan $\mathrm{pH}$ saliva setelah mengunyah keju cheddar.
\end{abstract}

Kata kunci: pH saliva, keju cheddar, demineralisasi

\section{Increasing Salivary pH By Chewing Cheddar Cheese}

\section{ABSTRACT}

The acidity degree of salivary $\mathrm{pH}$ is an important part in improving tooth integrity because it can increase the occurrence of tooth remineralization, where a decrease in salivary $\mathrm{pH}$ can cause tooth demineralization. One of the foods that can affect salivary $\mathrm{pH}$ is cheese. The purpose of this study was to determine the effect of eating cheddar cheese on increasing salivary $\mathrm{pH}$. This research is a quasi-experimental research, using a cross sectional approach using a pretest-posttest research design. The number of samples in this study were 67 people. Analysis using the paired test showed significant results $(p=0.012)$, so it can be concluded that there was an increase in salivary $p H$ after chewing cheddar cheese.

Keywords: salivary $\mathrm{pH}$, cheddar cheese, demineralization

\section{PENDAHULUAN}

Data Nasional Kesehatan Gigi di Indonesia saat ini menunjukkan prevalensi karies gigi sekitar $90 \%$ dari 238 juta penduduk Indonesia. Penyakit ini disebabkan karena adanya proses demineralisasi akibat proses dinamis penguraian ion-ion kalsium dan fosfat, serta daya fermentasi karbohidrat oleh mikroorganisme di dalam mulut yang menyebabkan terjadinya penurunan derajat keasaman $(\mathrm{pH})$ saliva, sehingga terkikis. Proses ini menimbulkan rasa sakit bila karies mencapai dentin, dan sakit luar biasa bila karies sudah mencapai pulpa. Agar tidak mudah terkena karies, maka haruslah terjadi keseimbangan $\mathrm{pH}$ saliva di dalam rongga mulut.

Saliva merupakan cairan mulut yang kompleks terdiri dari campuran sekresi kelenjar saliva mayor dan minor dalam rongga mulut.Saliva membantu pencernaan dan penelanan makanan, di samping itu juga untuk mempertahankan integritas gigi, lidah, dan mukosa mulut.Di dalam mulut, saliva adalah unsur yang penting yang dapat melindungi gigi terhadap pengaruh dari luar maupun dari dalam rongga mulut itu sendiri.Makanan dapat menyebabkan saliva bersifat asam maupun basa. Peran saliva terhadap proses karies bergantung 
pada komposisi, viskositas, $\mathrm{pH}$, dan mikroorganisme pada saliva. Derajat keasaman saliva merupakan faktor kunci keseimbangan antara asam demineralisasi gigi dan remineralisasi, $\mathrm{pH}$ saliva menjadi turun karena produksi asam dari bakteri setelah komsumsi karbohidrat. Di sisi lain, pH saliva akan naik jika asam dicuci dan dinetralkan menggunakan ion yang membentuk kandungan mineral gigi (kalsium, fosfat dan ion hidroksil). Derajat keasaman saliva juga naik ketika bakteri plak baik metabolisme asam memproduksi alkali serta ammonia dari senyawa nitrogen yang ditemukan pada makanan dan saliva, ion kalsium, fosfat mulai memperbaiki kristal mineral yang rusak dari enamel yang disebut dengan remineralisasi. Saliva berbentuk kental, jernih dan merupakan cairan yang disekresikan dari glandula parotid, submaksila, sublingual dan kelenjar mucus kecil lainnya pada mulut, saliva dihasilkan oleh kelenjar liur yang disekresikan kedalam rongga mulutdan disebarkan dari peredaran darah melalui celah antara permukaan gigi dan gusi yang disebut sulkus gingivalis. Komposisi saliva yang normal akan mempengaruhi keefektifan masing-masing fungsi saliva dalam mempertahankan kondisi yang konstan di lingkungan rongga mulut. Jika terjadi kerusakan pada kelenjar saliva seperti adanya obstruksi kelenjar atau penyakit sistemik yang menyebabkan berkurangnya saliva maka fungsi saliva terganggu.Untuk suatu larutan netral nilai $\mathrm{pH}$ adalah 7 dan semakil kecil nilai $\mathrm{pH}$ maka semakin tinggi keasaman suatu larutan.Larutan asam bila $\mathrm{pH}$ $<7$ dan dikatakan basa jika $\mathrm{pH}>7$. Adapun salah satu makanan yang dapat meningkatkan $\mathrm{pH}$ saliva adalah keju.Keju sendiri mempunyai banyak manfaat bagi kesehatan, khususya untuk gigi dan mulut, salah satunya adalah mencegah terjadinya karies dan dapat mempengaruhi $\mathrm{pH}$ saliva. Keju cheddar adalah salah satu makanan yang dapat menaikkan $\mathrm{pH}$ saliva karena kaya akan kalsium. Keju ini bermanfaat untuk mencegah demineralisasi gigi, mempercepat aliran saliva dan meningkatkan $\mathrm{pH}$ saliva. Kalsium susu mampu meningkatkan konsentrasi kalsium pada plak gigi, sehingga membantu terjadinya remineralisasi gigi. Keju juga mengandung kasein fosfopeptida yang penting untuk proses remineralisasi gigi. Asupan keju 5 gram perhari cukup efektif untuk memperkuat gigi dengan mencegah demineralisasi gigi, mempercepat aliran saliva dan meningkatkan $\mathrm{pH}$ saliva.Penelitian ini bertujuan untuk mengetahui apakah keju cheddar dapat meningkatkan $\mathrm{pH}$ saliva (Hapsari dkk, 2014).

\section{METODE}

Jenis penelitian yang digunakan adalah quasi experiment melalui pendekatan cross sectional dengan rancangan pretes-posttest control group design. Populasi dalam penelitian ini adalah masyarakat Lita-Litae, Saohiring, Kabupaten Sinjai yang berjumlah 205 penduduk. Pengambilan sampel dalam penelitian ini Simple Random Sampling sebesar 67 orang. Waktu penelitian pada bulan April-Mei 2021. Prosedur yang dilakukan, setiap calon subjek penelitian dipersiapkan untuk diberikan lembar penjelasan tentang penelitian yang dilakukan. Subjek diinstruksikan untuk menyikat gigi dan tidak makan dan minum selama 60 menit sebelum pengambilan saliva. Kemudian subjek penelitian diminta untuk mengumpulkan saliva dengan metode spitting yaitu saliva dibiarkan mengumpul di dasar mulut dengan menundukkan kepala, tidak menggerakkan lidah, menjaga bibir tetap tertutup dan tidak melakukan gerakan menelan. Hal tersebut dilakukan dalam waktu 60 detik, kemudian subjek diminta untuk meludahkan salivanya ke gelas ukur yang telah diberi label sebelum memakan keju dan $\mathrm{pH}$ saliva diukur menggunakan $\mathrm{pH}$ meter. Kemudian subjek diinstruksikan mengunyah keju sebesar 10 gram dengan selama 2 menit kemudian menelannya, 10 menit kemudian subjek diinstruksikan mengumpulkan subjek dengan metode spitting yaitu saliva dibiarkan mengumpul di dasar mulut dengan menundukkan kepala, tidak menggerakkan lidah, menjaga bibirnya tetap tertutup dan tidak melakukan gerakan menelan selama 60 detik, kemudian subjek diminta untuk meludahkan salivanya di gelas ukur 
yang sudah diberi label sesudah memakan keju dan $\mathrm{pH}$ saliva diukur menggunakan $\mathrm{pH}$ meter.

\section{HASIL DAN PEMBAHASAN}

Hasil

Hasil penelitian yang diperoleh disajikan dalam bentuk tabel berikut:
Tabel 1.

Distribusi Responden Berdasarkan Jenis Kelamin

\begin{tabular}{ccc}
\hline Jenis Kelamin & N & Persentase \\
Laki - Laki & 30 & $44,8 \%$ \\
Perempuan & 37 & $55,2 \%$ \\
\hline Total & 67 & $100 \%$ \\
\hline
\end{tabular}

Tabel 2. Kategori pH Saliva Sebelum Mengunyah Keju Cheddar

\begin{tabular}{ccccc}
\hline $\begin{array}{c}\text { Kategori keasaman } \\
\text { saliva }\end{array}$ & Frekuensi & Persentase & Valid Persentase & $\begin{array}{c}\text { Cumulative } \\
\text { Persentase }\end{array}$ \\
\hline asam & 23 & $34,3 \%$ & 34,3 & 34,3 \\
netral & 24 & $35,8 \%$ & 35,8 & 70,1 \\
basa & 20 & $29,9 \%$ & 29,9 & 100,0 \\
\hline Total & 67 & $100,0 \%$ & 100,0 & \\
\hline
\end{tabular}

Pada tabel 2 dapat terlihat bahwa sebagian besar dari 67 orang masyarakat Desa Saohiring yang dijadikan sampel penelitian mayoritas memiliki tingkat keasaman saliva yang netral $(35,8 \%)$ dan asam $(34,3 \%)$ sebelum mengunyah keju cheddar.

\section{Tabel 3.}

Nilai pH Saliva Sesudah Mengunyah Keju Cheddar

\begin{tabular}{ccccc}
\hline $\begin{array}{c}\text { Derajat keasaman } \\
\text { saliva }\end{array}$ & Frekuensi & Persentase & $\begin{array}{c}\text { Valid } \\
\text { Persentase }\end{array}$ & $\begin{array}{c}\text { Cumulative } \\
\text { Persentase }\end{array}$ \\
\hline asam & 14 & $20,9 \%$ & 20,9 & 20,9 \\
netral & 23 & $34,3 \%$ & 34,3 & 55,2 \\
basa & 30 & $44,8 \%$ & 44,8 & 100,0 \\
\hline Total & 67 & $100,0 \%$ & 100,0 &
\end{tabular}

Tabel 3 di atas menunjukkan perbedaan proporsi jika dibandingkan dengan tabel 2. Setelah mengunyah keju cheddar proporsi terbesar adalah sampel yang memiliki kondisi saliva yang basa $(44,8 \%)$.

Tabel 4.

Perbedaan Rata-rata pH Saliva Sebelum dan Sesudah Mengunyah Keju Cheddar

\begin{tabular}{ccc}
\hline & Rata-rata pH Saliva & P-value \\
\hline Sebelum & 6,90 & 0,012 \\
Sesudah & 7,32 & \\
\hline
\end{tabular}

Hasil penghitungan statistik menggunakan paired $t$ test dapat dilihat pada tabel 4. Pada tabel tersebut terlihat adanya perbedaan bermakna ratarata $\mathrm{pH}$ saliva sebelum $(6,90)$ dan sesudah $(7,32)$ 
mengunyah keju cheddar ( $p$-value=0,012).

Pembahasan

Salah satu cara untuk mengetahui potensi asidogenik suatu makanan adalah dengan cara mengukur $\mathrm{pH}$ Saliva setelah mengunyah atau mengonsumsi makanan tersebut. Meskipun $\mathrm{pH}$ saliva bukan satu-satunya parameter yang menjadi predisposisi karies gigi, tetapi pengukuran $\mathrm{pH}$ saliva dapat dijadikan sebagai alat pendidikan yang efektif untuk pendidikan kesehatan mengenai aspek nutrisi dan kesehatan gigi sebagai bagian dari konseling diet.(Tayab et al., 2012)

$\mathrm{pH}$ saliva dipengaruhi oleh laju alir, durasi stimulasi dan konsentrasi kalsium. oleh karena itu, sebelum pengujian dengan keju cheddar, subjek diinstruksikan untuk menyikat gigi dan tidak makan dan minum selama 60 menit sebelum pengambilan saliva. Hal ini untuk mendapatkan standarisasi nilai $\mathrm{pH}$ dasar atau nilai $\mathrm{pH}$ sebelum mengunyah keju cheddar. Setlah itu subjek diinstruksikan untuk mengunyah keju cheddar selama dua menit dan menelannya, lalu pencatatan $\mathrm{pH}$ saliva dilakukan 10 menit kemudian.

Dalam penelitian ini, terlihat peningkatan $\mathrm{pH}$ saliva setelah mengunyah keju cheddar (tabel 4). Peningkatan ini $\mathrm{pH}$ saliva ini serupa dengan hasil penelitian terdahulu yang dilakukan oleh Nadia Hapsari (2014) dalam penelitian serupa, yang menyatakan bahwa dengan memakan keju cheddar dapat meningkatkan $\mathrm{pH}$ Saliva. Hal ini karena karena keju cheddar yang merupakan salah satu produk susu yang kaya kalsium. Golongan protein yang paling banyak dijumpai pada produk susu adalah kasein, yaitu sekitar $80 \%$ dan dijumpai pada protein susu sapi dalam bentuk suspense partikel, yaitu casein miscelles mampu memodifikasi komposisi mikrobial plak gigi sehingga mengurangi potensi kariogenik dari mikrobal plak gigi. Mengunyah keju cheddar dapat mencegah demineralisasi enamel dengan mekanisme yang berbeda. Pertama, menstimulasi aliran saliva yang berguna untuk self cleansing dan menetralkan asam. Kedua, mampu menghalangi plak bakteri sehingga mengurangi produksi asam. Ketiga, dengan meningkatkan substansi alkalin, kalsium, inorganic fosfat dan kasein yang menurunkan demineralisasi serta meningkatkan remineralisasi. Asupan keju 10 gram perhari cukup efektif mempercepat aliran saliva (air liur), dan meningkatkan $\mathrm{pH}$ saliva.

\section{KESIMPULAN DAN SARAN}

Berdasarkan hasil penelitian yang telah dilakukan dapat disimpulkan bahwa mengunyah keju cheddar dapat meningkatkan nilai $\mathrm{pH}$ saliva. Sehingga mengunyah keju cheddar dapat disarankan dan dijadikan contoh dalam pendidikan diet dan kesehatan gigi sebagai salah satu konsumsi yang baik untuk meningkatkan $\mathrm{pH}$ saliva dan mencegah terjadinya demineralisasi email.

\section{DAFTAR PUSTAKA}

Akbarisyah, Tri, Permata, Diah Tanjung, Astuti, Desi Sri. 2011. Anatomi, Histologi dan Fisiologi dari Kelenjar Saliva. Makalah. Studi Kedokteran Gigi. Fakultas Kedokteran Gigi. Universitas Sriwijaya.

Amalia, Resti. 2013. Gambaran Status pH dan Volume Saliva Pada Pengguna Kontrasepsi Hormonal. Skripsi. Fakultas Kedokteran Gigi: Universitas Hasanuddin.

Andryas, Ika. 2004. Peranan Saliva Pengganti Pada Penderita Xerostomia. Skripsi. Universitas Sumatera Utara: Medan.

Anggraeni, N. 2007. Latar Belakang dan Pembuatan Keju.(eprints.ums.ac.id $>B A B \_$II ). Diakses pada Tanggal 25 januari 2019.

Hapsari, Nadia Fitri, Ismail, Ade. Santoso, Oedjiono. 2014. Pengaruh Konsumsi Keju Cheddar 10 Gram Terhadap pH Saliva. Odonto Dental Jurnal Fakultas Kedokteran Gigi. Universitas Islam Sultan Agung Semarang.

Kasuma, Nila dan Biomed M. 2015. Fisiologi dan Patologi Saliva. Padang: Andalas 
University Press.

Kidd, E, A, M dan Sally Jonyston Bechal. 1992.

Dasar-Dasar Karies Penyakit dan

Penanggulangannya. Jakarta: Buku Kedokteran EGC.

Kurniawati. 2010. Penurunan Kapasitas dan

Aktivitas Antioksidan Saliva Akibat Merokok. Oral Biologi Dental Journal vol 2, no2, 1-6. Hasibuan, R,G,H. 2016. Perbedaan $\mathrm{pH}$ dan Laju Alir Saliva Sebelum dan Sesudah Mengunyah Cokelat dan Keju Cheddar. Skripsi. Fakultas Kedokteran Gigi. Universitas Sumatera Utara: Medan.
Rakhmah,R,F. 2008. Latar Belakang Keju. (eprints.ums.ac.id >BAB_l ). Diakses pada Tanggal 25 januari 2021.

Rizal, F,Y. 2017. Perbedaan Laju Alir dan Kapasitas Buffer dan Kadar Ion Kalsium Pada Wanita Hamil. Fakultas Kedokteran Gigi. Universitas Sumatera Utara: Medan.

Tayab, T., Rai, K., Kumari, V., \& Thomas, E. (2012). Tabassum Tayab et al Effect of Chewing Paneer and Cheese on Salivary Acidogenicity: A Comparative Study. Int J Clin Pediatr Dent, 5(1), 20-24. https://doi.org/10.5005/jp-journals-100051128 